politike u ovim zemljama, kako bi se moglo što uspješnije odgovoriti na specifične socijalne izazove u ovim državama. Na panelu su sudjelovali: Mirna Jusić s Karlovog Sveučilišta u Pragu, Jelena Matančević sa Sveučilišta u Zagrebu, Jekaterina Navickë sa Sveučilišta u Vilniusu, Lucie Novotna sa Sveučilišta Masaryk te Anis Ben Brik iz Qatar Foundation.

Jelena Matančević

Studijski centar socijalnog rada Pravnog fakulteta Sveučilišta u Zagrebu

doi: 10.3935/rsp.v27i1.1706

\section{ERNOP KONFERENCIJA 2019.: PHILANTROPY IN THE SPOTLIGHT? RESOURCES, REPUTATION AND ACHIEVEMENTS}

\section{Basel, 4.-5. lipnja 2019.}

9. međunarodna znanstvena konferencija Europske istraživačke mreže o filantropiji (European Research Network on Philanthropy - ERNOP) održana je u Baselu, 4. i 5. lipnja 2019. godine. Filantropija nije novi fenomen, međutim, zadnjih godina raste njen značaj u Europi i u svijetu u naslovljavanju različitih društvenih i razvojnih izazova. Rastuća uloga i očekivanja od filantropije otvaraju i važna pitanja, poput motiva kojima se vode donatori i filantropske organizacije, ulogu filantropije u kontekstu europskih socijalnih država, kao i odnosa između filantropskih organizacija i drugih dionika. Istovremeno, rast značaja filantropije postavlja i sve veće zahtjeve za transparentnošću, te razumijevanja utjecaja i ograničenja filantropije. Domaćin konferencije bio je Centar za filantropske studije (Center for Philanthropy Studies - CEPS)
Sveučilišta u Baselu. Njegov direktor, Georg von Schnurbein u pozdravnom govoru naglasio je bogatu tradiciju i značaj filantropije za Basel, jedan od gradova s najvećom gustoćom zaklada u svijetu.

Plenarno izlaganje održao je Bob Reich, profesor političkih znanosti i filozofije na Sveučilištu Stanford. Reich je i jedan od ravnatelja Centra za filantropiju i civilno društvo na istom sveučilištu. Svoje plenarno izlaganje temeljio je na novije objavljenoj knjizi Just Giving: Why Philanthropy is Failing Democracy and How It Can Do Better, u kojoj kritički propituje normativno shvaćanje filantropije $\mathrm{i}$ ističe $\gg$ tamnu stranu « uloge filantropije u demokratskim društvima, u kontekstu rasta nejednakosti. Prema Reichu, filantropija se ne bi trebala opravdavati kriterijem učinkovitosti, već treba vrednovati ciljeve filantropskog djelovanja, nije svaki cilj vrijedan u demokratskim društvima. Također, valja vrednovati način na koji je bogatstvo stečeno, je li on bio dobar. Drugim riječima, filantropijom se ne smije »popravljati« šteta učinjena stvaranjem bogatstva. Kritički razmatra uvriježeno opravdavanje filantropije kako je bolje darivati nego držati bogatstvo za privatnu svrhu i privatnu potrošnju; on filantropiju razumijeva kao demonstraciju moći bogatih nad drugima, što je opasnost za demokratska društva. U tom kontekstu, kritizira i porezne povlastice za darivanje. Pozitivnu stranu filantropije i društveni doprinos zaklada Reich vidi tome što one pružaju mogućnost testiranja novih rješenja socijalnih problema i inovacija u dugoročnoj perspektivi, za razliku od vlada, koje imaju kraće mandate i čiji su ciljevi kratkoročniji.

Drugo plenarno izlaganje održala je Pamala Wiekping, profesorica na Vrije Sveučilištu u Amsterdamu, Centru za filantropske studije te gostujuća profesorica na Lilly Family School of Philantrophy u Indianapolisu. Izlaganje na temu stvaranja darežljivijeg društva, prof. Wiekping je 
dala perspektivu u kojoj je naglasila svijetlu stranu filantropije, između ostalog, ističući intrinzične motive za darivanje poput altruizma, psihološke nagrade i drugih. Potkrepljujući svoje teze mnoštvom konkretnih primjera, istakla je važnost darivanja na mikrorazini, kao doprinos stvaranju darežljivijeg društva. Takvi primjeri darivanja, i drugi oblici filantropije uglavnom nisu »zahvaćeni« istraživanjima, koja također ne vode računa o kulturnim razlikama kada je u pitanju filantropija. Prema tome, Wiekping ističe problem operacionalizacije filantropije, njene definicije i geografske pokrivenosti u istraživanjima filantropije, koja su dominantno koncentrirana na zemlje zapadne Europe i Sjeverne Amerike. Navedeno rezultira jednodimenzionalnim, »zapadnjačkim《 razumijevanjem filantropije, te posljedično pristranim rangiranjem zemalja u istraživanjima o darivanju. Ističe se potreba za razvojem inkluzivnog, komparativnog i interdisciplinarnog pristupa $u$ istraživanju filantropije.

Za razliku od prva dva, treće plenarno izlaganje bilo je iz perspektive praktičara. Izlagala je Lynda Manssons iz MAVA zaklade, kao primjera obiteljske zaklade koja je ostvarila snažnu suradnju s lokalnim dionicima u području zaštite bioraznolikosti. MAVA zaklada specifičan je primjer zaklade zbog razloga što je zakladnik prilikom osnivanja bio odredio datum gašenja zaklade, 2022. godine. Istaknute su prednosti ovakvih zaklada, ali i prepreka s kojima se susreću vezanim uz gašenje zaklade. Istaknuta su nastojanja zaklade u ostvarenju utjecaja u zajednici, ostavljanju nasljeđa nakon što se zaklada ugasi, prije svega ulaganjem u organizacijski razvoj, ulaganjem u održivost financiranja privlačenjem drugih donatora te izgradnjom savezništva u zajednici.

U brojnim paralelnim sesijama predstavljeni su teorijski radovi i najnovija istraživanja, koji su naslovili širok raspon tema, uključujući pitanja socijalnih inovacija i filantropije, skupnog financiranja, strategija namicanja sredstava, filantropije i socijalnog ulaganja, obiteljskih zaklada, zaklada lokalnih zajednica, međusektorske suradnje i vladavine, zakonskog i poreznog okvira za filantropiju, korporativne filantropije i mnoge druge teme. U nastavku ćemo se osvrnuti na nekoliko sesija i izlaganja.

U sesiji na temu izgradnje filantropskog ekosustava, Gojko Bežovan i Jelena Matančević s Pravnog fakulteta u Zagrebu dali su povijesnu i razvojnu perspektivu uloge zakladništva i filantropije u Hrvatskoj. Istaknuta je važna povijesna uloga zaklada u modernizaciji hrvatskog društva s prijelaza iz 19. u 20. stoljeće, te s druge strane, noviji izazovi i potencijali razvoja zakladništva u Hrvatskoj. Potencijali za značajniji razvoj zakladništva i poticanje darivanja prikazani su kroz nekoliko studija slučajeva. JeanMarc Fontan sa Sveučilišta u Montrealu izlagao je na temu filantropskog ekosustava u Quebecu. Zadnjih godina dolazi do povećanja vidljivosti zaklada te jačanja strateške suradnje dionika. Bojana Radovanović sa Sveučilišta u Beogradu predstavila je izazove konceptualizacije i mjerenja filantropije, na primjeru istraživanja filantropije u Srbiji. Pokazuje se kako rezultati istraživanja filantropije uvelike ovise o njenoj konceptualizaciji. Neformalno darivanje najčešće je izostavljeno u istraživanjima filantropije, što rezultira iskrivljenom slikom o razmjerima darivanja u zemljama u kojima je praksa neformalnog darivanja učestala. Rad Bojane Radovanović ujedno je nagrađen kao najbolji rad konferencije.

U sesiji na temu filantropije u makroperspektivi, Marko Galjak s Instituta za društvene znanosti iz Beograda prikazao je analizu mreža temeljem Giving Balkans istraživanja o darivanju u zemljama Zapadnog Balkana. Hrvatska se ovdje pokazuje kao vrlo centralizirana, s manjom, gušćom i centraliziranom mrežom donatora. Kinga 
Horvath i suradnice s Lilly Family School of Philanthropy predstavile su rad na temu mapiranja budućnosti filantropije. Raspravlja se o ulozi ekonomskih, političkih i regulatornih čimbenika i njihovom utjecaju na budući razvoj filantropije, temeljem podataka iz Global Philanthropy Environment Index (GPEI). Kao najznačajniji čimbenici koji će utjecati na budućnost filantropije na nacionalnoj razini ističu se online darivanje, korištenje društvenih medija, međusektorska suradnja i drugi, dok se kao prepreke prepoznaju nepodržavajuće političko okružje te povećana regulacija, osobito vezana uz prekogranično darivanje.

Odnos vlasti prema filantropiji bila je tema iduće sesije. Johan Vamstad s Ersta Skonda University iz Stockholma prezentirao je komparativnu studiju poreznih poticaja za filantropiju, objašnjavajući razlike teorijom socijalnog podrijetla. Primjerice, Švedska nije nikada uvela porezne povlastice za darivanje; smatra se neopravdanim javnim novcem, odnosno porezima financirati privatna darivanja. Istaknuto je načelo demokratske kontrole nad javnom potrošnjom, a politike potpore organizacijama civilnog društva trebaju se temeljiti na kriteriju prioriteta u socijalnim potrebama. Theo Schuyt i suradnici s Vrije Sveučilišta u Amsterdamu prezentirali su primjer EUFORI studije, naručene od Europske komisije, čiji su nalazi objavljeni u izvješću Giving in Evidence Report. Europska komisija i Opća uprava za istraživanje i razvoj posvećuju sve veću pozornost potencijalima filantropije $u$ cilju jačanja gospodarstva EU-a i povećanja njene kompetitivnosti u svijetu. Oto Potluka sa Sveučilišta u Baselu govorio je o građanskoj zauzetosti u kontekstu suproizvodnje u programima urbanog razvoja. EU politike i instrumenti u području urbanog razvoja otvaraju prostor suradnje vlasti i civilnog društva, odnosno građana. Temeljem nekoliko studija slučajeva, istražuju se različiti tipovi vodstva u programima urbanog razvoja, pri čemu najveći prostor za suproizvodnju i sudjelovanje građana otvara institucionalizirano partnerstvo između javnog sektora i organizacija civilnog društva u hitnim situacijama i pitanjima koja podrazumijevaju kompleksnu i koordiniranu suradnju.

ERNOP konferencija važna je prilika za susret znanstvenika te praktičara iz područja filantropije i zakladništva te prilika za raspravu o budućem razvoju i potencijalima filantropije za doprinos rješavanju složenih društvenih problema i izazova. Valja istaknuti kako je na konferenciji 2019. godine bila i nešto veća zastupljenost radova i istraživača iz zemalja jugoistočne Europe. Naredna ERNOP konferencija održat će se 2021. godine u Dublinu.

Jelena Matančević

Studijski centar socijalnog rada Pravnog fakulteta Sveučilišta u Zagrebu 